testing as part of the private medical insurance market may severely aggravate the problem of sharing financial responsibility for insurance between private and public programmes. In the United States a whole range of policy options to address the problem is being discussed in Congress. These vary from banning or limiting the use of testing and using incentives and subsidies to provide private insurance for the uninsured or uninsurable to enhancing public programmes and federal payments for the uninsurable. The creation of larger risk pools for health insurance and a greater role for the federal government (supported by both Democrats and Republicans) are both under consideration. It would be a pity if Britain went in the opposite direction because of a failure to understand this and other consequences of encouraging a private medical insurance market.

C R PATON

Lecturer,

Centre for Health Planning and Management,

University of Keele, Staffordshire ST5 5BG

1 United States Congress Office of Technology Assessment. Medical testing and health insurance. Washington, DC: United States Government Printing Office, 1988. OTA/H/384.

United States Congress Office of Technology Assessment. AIDS and health insurance. An OTA survev. Washington, DC: United States Government Printing Office, 1988.

United States Congress Office of Technology Assessment. The impact of AIDS on the Kaiser Permanente Medical Care Program (Northern Califormia region. Washington, DC: United States Government Printing Office, 1988.

\title{
The national curriculum and medical education
}

\section{An opportunity to modernise medical education}

Detailed planning to introduce a national curriculum is now under way in Britain, and the curriculum carries implications for medical education. One argument is that an extra year might be needed in the medical curriculum because entrants will have had less exposure than present students to scientific subjects. But this would be a disaster as it would perpetuate the present old fashioned form of medical education. Rather, the arrival of the national curriculum should serve as an opportunity for modernising medical education.

The science working group of the National Curriculum Council has recommended that all 14-16 year olds should spend a maximum of a fifth of their time on a broad and balanced science curriculum that emphasises scientific thinking and know how. ' In formulating its proposals the group has turned away from a "pot filling" concept of science education, basing its approach instead on an understanding of how students learn science.

Students engaged in the new curriculum will spend about $10 \%$ less curricular time in science than students taking three science $\mathrm{O}$ levels, and fewer topics will be covered. Yet concerns that this may mean a reduction in students going on to study chemistry further ${ }^{2}$ do not seem to be justified: the rate of uptake of $A$ level science was twice as high among pupils studying integrated science as among those doing three science $\mathrm{O}$ levels. ${ }^{3}$ Pupils who had taken three $\mathrm{O}$ level sciences did score better in A level chemistry than those who had taken an integrated course, but this may have been because the pupils with the three science $\mathrm{O}$ levels also took $\mathrm{A}$ level biology. ${ }^{+}$It is argued to be the combination of biology with chemistry that makes the difference. If this is the case then we need to understand why because we also know that having $\mathrm{A}$ level biology is one of the few predictors of success at medical school.

There is little evidence that a chasm is about to develop between A level and undergraduate study. Despite claims and counterclaims,${ }^{6}$ the case for a return to something like a premedical year for all students seems weak. The changes in A levels currently proposed are not major. For example, the Joint Matriculation Board is planning a $10-15 \%$ reduction in its chemistry syllabus for 1990 , but this will not affect the content of organic chemistry. The Higginson report, which recommended a more radical reduction in A level content, has been rejected by the government.

Yet there are other more compelling reasons for not adding an extra year. Such a strategy would enable medical schools to perpetuate the "pot filling" approach to teaching and learning that we now know is largely responsible for the unsatisfactory state of undergraduate medical education. Research is mapping out the alarming extent to which it is possible for students to take courses, succeed in examinations, and yet fail to understand and use the fundamental concepts in their disciplines. ${ }^{8}$

Our students enter medical schools with high motivation and highly desirable approaches to learning. Yet they rapidly experience a loss of motivation, growing cynicism, and difficulty in seeing the relevance of much of the material they are asked to learn. ${ }^{9}$ Their approaches to study deteriorate appreciably over the first few months. ${ }^{10}$ The upshot of this is that in their clinical work they can neither remember nor use the basic science information they apparently learned successfully for examinations a few months before. This happens because our courses are predominantly organised in ways that fail to lead students to see that their task is to relate their concrete clinical experience to abstract concepts in basic science. Our courses and assessment systems encourage students to put their learning into compartments: students do not fail the courses, but the courses fail the students. To serve up more of the same during the extra year would be a disaster, add insult to injury, and threaten standards by lowering still further the quality of student learning.

This old "pot filling" model of professional education is now worn out and discredited." 12 Yet it is implicit in the division between preclinical and clinical courses that is still fundamental to medical education. Some aspects of the national curriculum and recent research in medical education ${ }^{9}$ may provide us with pointers toward a better educational model that would make the nature of professional practice and an understanding of how students learn that practice the focal point of educational endeavours.

Lecturer in Medical Education,

WILLIAM FLEMING

Medical School

University of Birmingham, Birmingham B15 2TJ

\footnotetext{
1 Department of Education and Science and the Welsh Office. Science for ages 5 to 16 . Science working group, final report. London: National Curriculum Council, 1988. with those of pupils who take all three separate sciences? British Educational Research foumal $1988 ; 14: 149-54$

McManus IC, Richards P. Prospective survey of performance of medical students during preclinical years. Br.Med f 1986;293:124-7.

6 Lodge B. Warnock attacks academic straight-jacket. Times Educutional Supplement 1988 Nov 18:4 Department of Education and Science and the Welsh Office. Adz'uncing A levels. London: HMSO, 1988. Higginson report

8 Ramsden P, ed. Improving learning: new perspectives. London: Kogan Page, 1988.

9 Coles CR. The actual effects of examinations on medical student learning. Assessment and Evaluation in Higher Fducation 1987;12:209-19.

10 Coles CR. A study of the relationship between curriculum and learning in undergraduate medical education [PhD thesis]. Southampton: University of Southampton, 1985:139-54.

1 Schon DA. The reflective practitioner. New York: Basic Books, 1983.

12 Schon DA. Educating the reflective practitioner. San Francisco: Josser-Bass, 1987.
} 